12. Menelis Francis L and Pai Vittal T (1969) : Malignant lymphoma of head and neck. The laryngoscope : 1076-1086.

13. Paul JR (1988) : Lymphatics and lymph nodes. Quoted in Bailey and Love's Short Practice of Surgery $20^{\text {th }}$ edition, pp. 125-131. Published by Hazell Watson and Viney Ltd., Aylesbury, Bucks, England.

14. Rohrberg R, Krug K, Krahl D et al (1986) : Clinical aspects and prognosis of highly malignant Non-Hodgkin's lymphomas. $\mathrm{Z}$ Gesamte Inn Med 1:41 (19) 528-38.
15. Urquhart A and Berg R (2001) : Hodgkin's and Lymphatic of the head and neck Laryngoscope ; 111 (9): 1565-9.

\section{Address for Correspondence :}

Dr. S.K. Verma,

5-F, Model Town,

Patiala (Punjab)

Pincode 147001.

\title{
LARYNGEAL MELANOSIS
}

\author{
V Dutta', P S Reddy ${ }^{2}$
}

\begin{abstract}
We describe a case laryngeal melanosis in a 62 year old male. The pigmentation was visible on gross examination during laryngoscopy and histologically a single foci showing changes of carcinoma in situ was identified. The biopsy tissue, however did not reveal any frank changes of malignancy.
\end{abstract}

Pigmentation of the larynx is not very common. It has been seen to occur in benign as well as malignant lesions and it can affect any part of the larynx. The pigment containing dendritic cells are present in the basal layer of squamous epithelium lining the laryngeal lumen. The presence of these pigment containing dentritic cells in the laryngeal mucosa and more generally, in non ectodemal sites, raises the problem of their histogenesis. The present paper deals with a case of diffuse melanin pigmentation of the laryngeal mucosa, observed in association with a focus of carcinoma in situ.

\section{CASE REPORT}

A 60 year old man developed hoarseness of voice since 6 months and pain on swallowing about a month prior to reporting to the Army Hospital. He had no systemic manifestations like fever; weight loss or loss of appetite. The past/present history did not reveal any significant information and family $\mathrm{H} / \mathrm{O}$ tuberculosis was absent. General and Physical examination at the time of admission was non-contributory. The patient underwent laryngoscopic examination which revealed an intraluminal dark coloured growth in the left false vocal cord and medical aspect of aryepiglottic fold. The Vocal cords were normal. Biopsies were taken at random from the growth

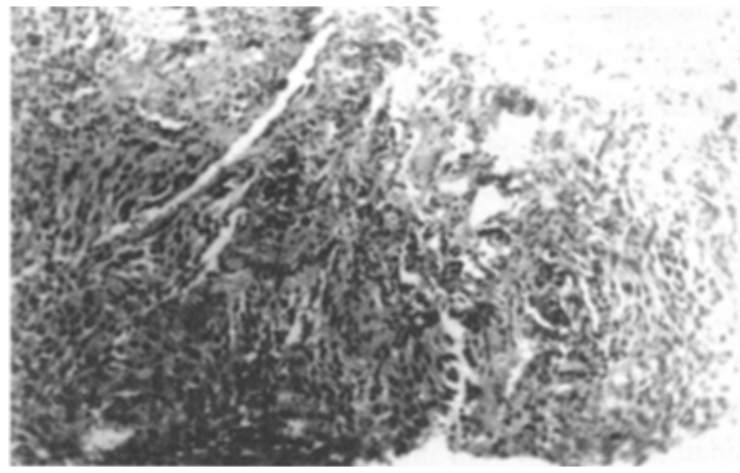

Fig. I : Carcinoma in situ changes in the epithelium along with basal layer pigmentation (H\&E, X 100).

and sent for histological evaluation.

Histopathology

Microscopic examination of the $\mathrm{H}$ \& $\mathrm{E}$ (Hematoxylin \& Eosin) stained tissue sections revealed a lining of hyperplastic squamous epithelium with uniform pigmentation in the basal layer. Single focus, within the connective tissue stroma showed singly scattered, numerous pigment containing cells associated with changes of carcinoma in situ in the epithelium in that region (Fig I). The intracellular pigment stained positively with

'Pathologist, 151 Base Hospital, , C/O 99 APO, ${ }^{2} \mathrm{Head}$ of Department \& Senior Advisor Pathololgy, Army Hospital, Delhi Cantt, New Delhi-110010 


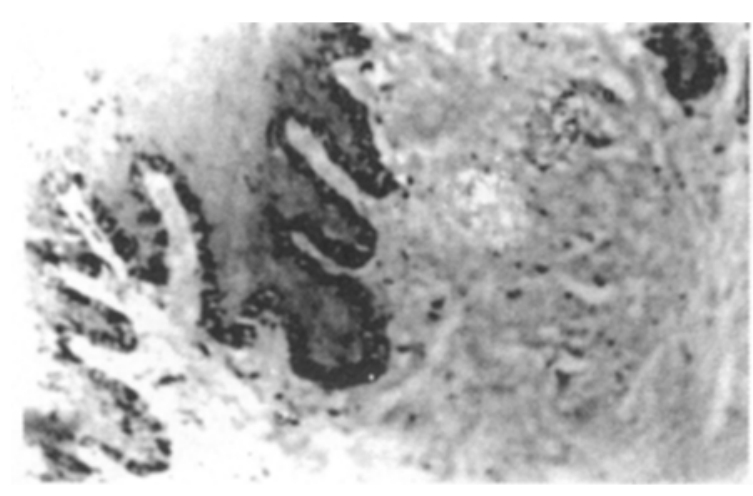

Fig. II : Pigmentation of the basal layer of epithelium (Masson Fontana stain $\times 100$ )

Masson Fontana stain (Fig II), while with Prussian Blue it was negative. Additionally the pigment could also be decolorized by potassium permanganate, thereby confirming it to be melanin.

\section{DISCUSSION}

Laryngeal melanosis appears to be extremely rare. A review of English literature revealed 17 cases of laryngeal melanosis ${ }^{1}$, and $53 \%(9 / 17)$ of these demonstrated an associated laryngeal neoplasm (squamous cell carcinomas and 2 melanomas). Others studies have shown $37 \%$ of laryngeal melanosis cases to be associated with squamous cell carcinoma in their study ${ }^{2}$, benign melanosis being rare in them. In our case there was a diffuse melanin pigmentation of the laryngeal mucosa with a single focus of carcinoma in situ. These pigmented areas are often not detectable in the larynx by gross examination, in view of this, the present report of melanosis of the larynx is unique. There was extensive melanin content in the basal cell layer of squamous epithelium in the larynx as depicted in fig 2 , which is comparable to that reported in other studies ${ }^{2,3}$.

Various propositions have been put forward to explain this phenomenon. The origin of these cells or melanocytes in any other nonintegumentary or extraocular sites has been a subject of speculation. Attempts have been made to explain this by transformation of epithelial cells to melanoblasts (melanogenic metaplasia) ${ }^{4,5}$. Others have suggested migration of melanoblasts with the mesoderm to different organs with subsequent maturation and melanin production ${ }^{6}$ or transformation of neural tissue into melanin producing cells ${ }^{5}$ to account for melanin at these sites. Electron microscopy has been noncontributory and has yielded contradictory findings ${ }^{3}$. Of these pathogenic mechanisms it is impossible to tell which one applies to a particular case. It is well established that melanocytes, or dendritic cells are capable of melanin production, with the exception of those present in the retina pigment epithelium which arise in the neural crest and migrate together with the ectoderm to the peripheral sites. Pigment containing cells have been reported in neuroectodermal sites, for instance in oral cavity in the Peutz Jeghers Syndrome, other sites include the vagina, cervix and endometrium ${ }^{3}$.

\section{CONCLUSIONS}

Melanin pigmentation of the larynx is not commonly detected by gross examination. In view of this, the present report of melanosis of the larynx is unique. Pre-existing melanosis is becoming more noted with the mucosal neoplasms, however to conclude these as premalignant lesions would be premature and needs a better definition, in fact it has been suggested by some of group of workers that melanocytic activity in unusual sites could be a sign of occult malignancy.

\section{REFERENCES}

1. Batsaki JG, Suarez P, Nagger AK (1998) : Mucosal Melanomas of the head and neck. Ann Otol Rhinol Laryngol 107:626630 .

2. Har-El-G, Ladinsky S, Borderon M, Santos V, (1990) : Melanosis of the larynx. Ann Otol Rhinol Laryngol, 99: 640-642.

3. Nakai T, Rappaport $\mathrm{H}$ (1963) : A study of the pathogenesis of experimental melanotic tumors resembling cellular naevi; the evidence in support of their neurogenic origin. Am $J$ Pathol 43:175-99.

4. Nicholas SE, Reams WM (1960): The occurrence and morphogenesis of melanocytes in connective tissue of the PET/ MCV mouse strain. J Empbryol Exp Morphol 8:24-35.

5. Shivas AA, Mac Lennan WD (1963): Melanogenic metaplasia of mucous glands. Br J Cancer 17:41 1-414.

6. Pesce C, Tonicini C (1983): Melanin pigmentation of the larynx. Acta Otolaryngol 96: 189-92. 